\title{
CONSIDERATIONS REGARDING THE LAND SNAILS FROM THE UPPER TIMIŞ RIVER VALLEY (BANAT, ROMANIA)
}

Voichiţa GHEOCA *

* "Lucian Blaga" University of Sibiu, Faculty of Sciences, Department of Ecology and Environment Protection, Dr. Ion Raţiu Street 5-7, Sibiu County, Romania, RO - 550012, vgheoca@yahoo.com

DOI: 10.2478/trser-2013-0037

KEYWORDS: Romania, Timiş River, terrestrial gastropods, Drobacia banatica.

\section{ABSTRACT}

The paper focuses on land snail fauna from the upper Timiş River valley. The analyzed material originates from seven locations starting with the Trei Ape area (Semenic Mountains) and ending with Petroşniţa (upstream Caransebeş). Samplings were made during one campaign in August 2012. A total of 24 species was identified, belonging to 14 families. The area analyzed exhibits a reduced diversity due to the type of substratum represented by crystalline schist, the conifer dominated vegetation in the mountain area, and the anthropogenic impact of tourism, intensive grazing, cutting of woody vegetation in meadows and waste storage. The presence in Sadova Veche of the species Drobacia banatica, listed on Annex II of the EU Habitats Directive, underlines the importance of riparian habitat preservation for the conservation and dispersion of land snail species. (Roumanie).

RÉSUMÉ: Quelques considérations sur les gastéropodes terrestres de la rivière Timiş

Le travail présente quelques aspects concernant la faune des gastéropodes terrestres du cours supérieur de la rivière Timiş (Banat, Romania). Le matériel analysé provient des sept points de prélèvement localisés entre Trei Ape (Montagne du Semenic) et Petroşniţa (en amont de Caransebeş). Les prélèvements ont été réalisés au cours d'une seule campagne en août 2012. 24 espèces de gastéropodes terrestres appartenant à 14 familles ont été identifiés. La zone analysée possède une diversité très faible en gastéropodes terrestres, d'une part, en raison de la nature du substrat, représenté par des schistes cristallins dans la région montagneuse, et la végétation dominée par la présence de conifères, d'autre part, à cause de l'impact anthropique caractérisé par le tourisme, le pâturage intensif, la coupe de la végétation ligneuse des prairies et du stockage des déchets. La présence de Drobacia banatica, espèce de l'annexe II de la Directive Habitats, à Sadova Veche, souligne l'importance des habitats riverains pour la préservation et la dispersion des espèces de gastéropodes terrestres.

REZUMAT: Consideraţii privind moluştele terestre din valea râului Timiş (România).

Lucrarea prezintă aspecte privind fauna de gastropode terestre din bazinul Timişului superior. Materialul analizat provine din şapte puncte de colectare localizate în zona Trei Ape - Petroşniţa, colectările fiind realizate în cursul unei campanii unice în 2012. În urma analizei materialului au fost identificate 24 specii de gastropode terestre, aparţinând la 14 familii. Zona analizată prezintă o divesitate foarte scăzută, datorată tipului de substrat reprezentat de şisturi cristaline şi vegetaţiei din zona montană dominată de prezenţa coniferelor, dar şi modificărilor de origine antropică - turism, păşunat intensiv, tăieri ale vegetatiei lemnoase din lunci, depozitare de deşeuri. Prezenţa speciei Drobacia banatica, specie din anexa II a Directivei Habitate la staţia Sadova Veche, subliniază importanţa conservării habitatelor ripariene pentru conservarea şi dispersia speciilor de gastropode terestre. 


\section{INTRODUCTION}

The humidity is one of the major factors affecting land snails, with essential effect on their distribution pattern. Some of the terrestrial gastropod species have developed physiological mechanisms to overcome desiccation, but most of them need large amounts of water in order to survive (Burton, 1983; Ward and Slotow, 1992). As they are animals with low mobility, the land snails are among the most vulnerable to the habitat fragmentation, process that has been rapidly accelerated by human activities (Nekola, 1999; Lindenmayer and Fischer, 2006; Mysák and Horsák, 2011). The development of agriculture has substantially reduced the extent of the habitats which are suitable for land snails especially in plains and plateau areas. Among these areas, the river valleys are between the habitats that are the most likely to preserve suitable conditions for land snails presence and therefore they are very important both for conservation and dispersion of land snail species.

The south western area of Romania has one of richest land snail faunas of Romania, due to the Mediterranean climatic influence. Nevertheless, the presence of extended limestone substratum, as in some areas like the Semenic Mountains, which are build on crystalline schist, offer different conditions to land snail development. The present study focuses on land snail fauna of the upper Timiş River valley (Banat, Romania).

\section{MATERIAL AND METHODS}

Samples were taken from seven sampling points, located in the upper course of the Timiş River, starting in Semenic Mountains near the spring (Trei Ape) at $870 \mathrm{~m}$ altitude and ending in Petroşniţa (near Caransebeş), in the plateau area at $250 \mathrm{~m}$ altitude. The sampling points are represented in figure number 1.

Semi quantitative samples were taken by collecting all the snails found in one hour (Cameron and Pokrysko, 2005). All the living snails and fresh shells were considered. The biologic material was identified using Grossu (1981, 1983 and 1987). The results were used to build the list of land snail species. Nomenclature follows Fauna Europaea v. 2.4 (Bank, 2011). Cluster analysis was performed using SYSTAT v 12.0 (Systat Software, 2009).

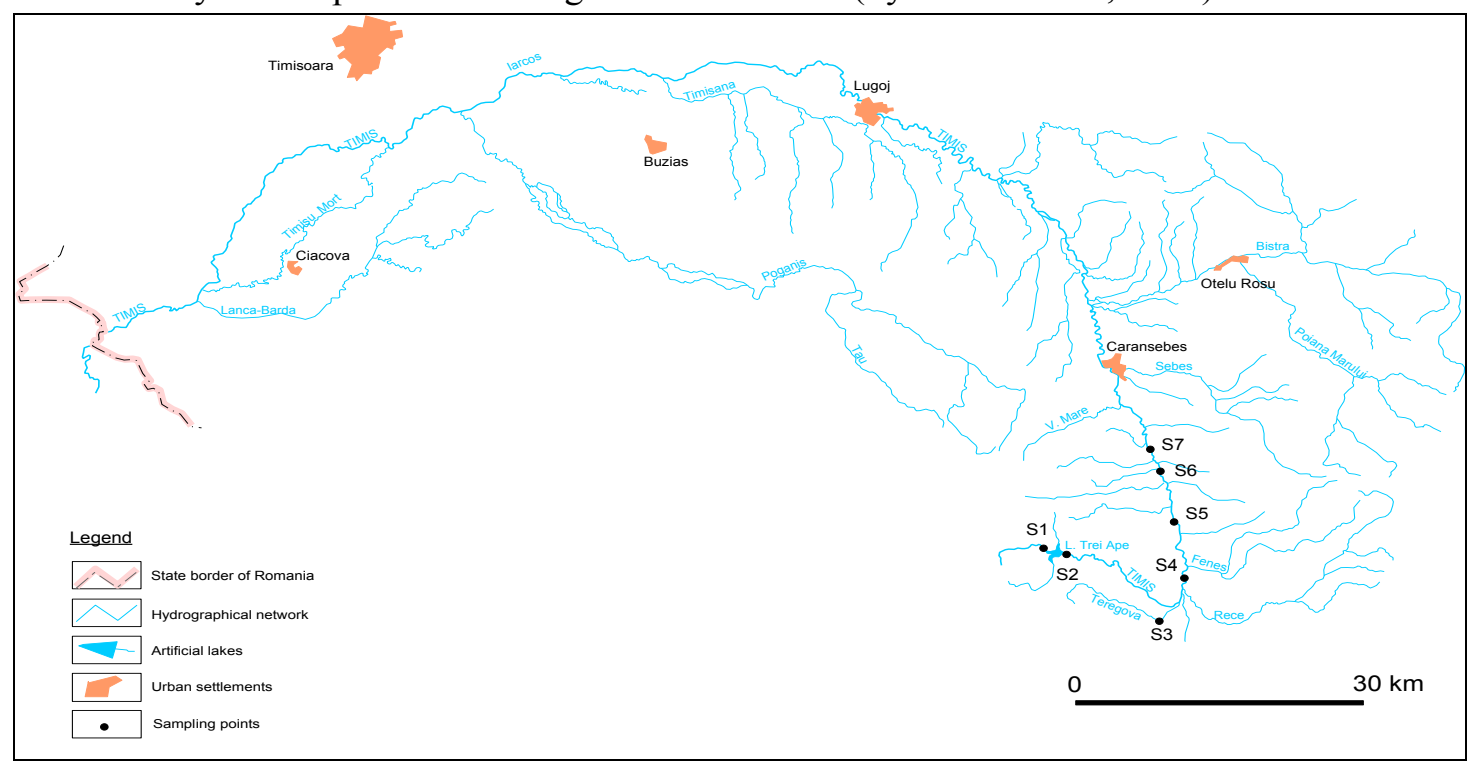

Figure 1: Sampling: S1 - Trei Ape upstream the lake; S2 - Trei Ape downstream the lake; S3Teregova; S4 - Armeniş; S5 - Sadova Veche; S6 - Bucoşniţa; S7 - Petroşniţa. 


\section{RESULTS AND DISCUSSION}

A number of 24 land snail species were found in the seven sampling stations, their occurrence is presented in table number 1 . The seven analyzed sampling stations can be grouped considering their geographic location in three distinct groups.

Table 1: The distribution in the area, ecology, and zoogeography of the terrestrial gastropods from Upper Timiş River valley. Abbreviation: humidity preferences: H hygrophylous, MH - mesohygrophylous, M - mesophylous; *old empty shells.

\begin{tabular}{|c|c|c|c|}
\hline Taxa & zoogeography & $\begin{array}{c}\text { humidity } \\
\text { preferences }\end{array}$ & $\begin{array}{c}\text { sampling } \\
\text { stations }\end{array}$ \\
\hline \multicolumn{4}{|l|}{ Fam. Carychiidae Jeffreys, 1830} \\
\hline Carychium tridentatum (Risso, 1826) & European & $\mathrm{H}$ & $1,2,4$ \\
\hline \multicolumn{4}{|l|}{ Fam. Cochlicopidae Pilsbry, 1900} \\
\hline Cochlicopa lubrica (O. F. Müller, 1774) & Holarctic & $\mathrm{H}$ & 4 \\
\hline \multicolumn{4}{|l|}{ Fam. Valloniidae Morse, 1864} \\
\hline Acanthinula aculeata (O. F. Müller, 1774) & European & $\mathrm{M}$ & 4 \\
\hline \multicolumn{4}{|l|}{ Fam. Punctidae Morse, 1864} \\
\hline Punctum pygmaeum Draparnaud, 1801 & European & $\mathrm{M}$ & 3,4 \\
\hline \multicolumn{4}{|l|}{ Fam. Clausilliidae A. Schmidt, 1857} \\
\hline Cochlodina laminata (Montagu, 1803) & European & MH & 3,4 \\
\hline Alinda viridana (Rossmässler, 1836) & Endemic & MH & 1 \\
\hline Alinda biplicata (Montagu, 1803) & European & MH & 4 \\
\hline \multicolumn{4}{|l|}{ Fam. Arionidae Gray, 1841} \\
\hline Arion circumscriptus Johnston, 1828 & European & MH & 2 \\
\hline \multicolumn{4}{|l|}{ Fam. Vitrinidae Fitzinger, 1833} \\
\hline Vitrina pellucida (O. F. Müller, 1774) & Holarctic & $\mathrm{M}$ & 1 \\
\hline \multicolumn{4}{|l|}{ Fam. Gastrodontidae Tryon, 1866} \\
\hline Zonitoides nitidus (O. F. Müller, 1774) & Holarctic & $\mathrm{H}$ & 4 \\
\hline \multicolumn{4}{|l|}{ Fam. Pristilomatidae Cockerell, 1891} \\
\hline Vitrea diaphana (Studer, 1820) & European & MH & 3 \\
\hline Vitrea crystallina (O.F. Müller, 1774) & European & MH & 1,2 \\
\hline \multicolumn{4}{|l|}{ Fam. Oxychilidae Hesse, 1927 (1879) } \\
\hline Aegopinella pura (Alder, 1830) & European & $\mathrm{M}$ & 1 \\
\hline Aegopinella minor (Stabile, 1864) & Central-South E & MX & 4 \\
\hline Morlina glabra (Rossmässler, 1835) & European & MH & 1 \\
\hline Carpathica langi (Pfeiffer, 1846) & Carpathic & MH & 1 \\
\hline \multicolumn{4}{|l|}{ Fam. Euconulidae H. B. Baker, 1928} \\
\hline Euconulus fulvus (O. F. Müller, 1774) & Holarctic & MH & 4 \\
\hline \multicolumn{4}{|l|}{ Fam. Bradybaenidae Pilsbry, 1939} \\
\hline Fruticicola fruticum (O. F. Müller, 1774) & Palearctic & $\mathrm{MH}$ & $3,5,6,7$ \\
\hline \multicolumn{4}{|l|}{ Fam. Hygromiidae Tryon 1866} \\
\hline Euomphalia strigella Draparnaud, 1801 & European & $\mathrm{M}$ & $3,4,5,6,7$ \\
\hline Monachoides incarnatus (O. F. Müller, 1774) & European & $\mathrm{M}$ & 1,2 \\
\hline \multicolumn{4}{|l|}{ Fam. Helicidae Rafinesque, 1815} \\
\hline Arianta arbustorum (Linnaeus, 1758) & European & $\mathrm{M}$ & 2 \\
\hline Drobacia banatica (Rossmässler, 1838) & $\begin{array}{l}\text { Central-Eastern } \\
\text { European }\end{array}$ & $\mathrm{M}$ & $1^{*}, 2^{*}, 5$ \\
\hline Cepaea vindobonensis (Pfeiffer, 1828) & European & MX & $3,5,6,7$ \\
\hline Helix pomatia Linnaeus, 1758 & $\begin{array}{l}\text { Central-Eastern } \\
\text { European }\end{array}$ & $\mathrm{M}$ & $\begin{array}{l}2,3,4,5, \\
6,7\end{array}$ \\
\hline
\end{tabular}


The first two sampling points are located in the Semenic Moutains (a subdivision of the Banat Mountains), near Trei Ape Lake. The area is built on crystalline schist, with a complex system of crevices that in the clay absence allow the rapid runoff of rainwater. The presence of spruce forests considerable decreases the occurrence of land snails. The area is the subject of a strong anthropogenic pressure represented by tourism and infrastructure construction, as well. The land snail fauna of this area is much poorer than it generally is in this type of habitat. A number of 12 species were present. Some species occurring most often in forests were found only in the area of the first two sampling points, as is the case of Alinda viridana, Vitrea crystalina, Aegopinella pura, Morlina glaber, Carpathica langi, Monachoides incarnatus, Arianta arbustorum. There were also found empty shells of Drobacia banatica, in an advanced state of degradation that cannot confirm the presence of the species in the area. These shells might have been carried by water or they can simply be the evidence of its previous presence in the area, probably before the increase of anthropogenic pressure.

The second sector is located in the Timiş-Cerna corridor whith a broad range of landscapes and a larger number of human settelments. Two sampling points were located in this area, S3 Teregova and S4 Armeniş. The first one is located upstream Teregova Gorges in a hilly area. A number of seven land snail species were found here, most of them ubiquiste like Helix pomatia, Cepaea vindobonensis, Fruticicola fruticum, Euomphalia strigella, but also Cochlodina laminata. This low diversity is most probably caused by grazing activities. The second sampling station of this sector was located in Teregova Gorges (upstream Armeniş), near the road but in a relatively izolated area. Remnants of the road development activities are present, but covered by vegetation able to preserve a certain degree of humidity and to serve as a food source for phytophagous species. Species like Carychium minimum, Cochlicopa lubrica, Punctum pygmaeum, Cochlodina laminata, Alinda biplicata, Zonitoides nitidus were found here, bringing this community more closely to the typical ones found in valleys from Transylvania (Gheoca 2005, 2007), yet presenting a relatively low diversity (nine species).

The third sector is located in the Caransebeş Plateau where the Timiş River has dug a broad valley with floodplain and well-developed terraces. This area has numerous human settlements with major impact on the river valley. The last three sampling points are located in this area near villages, with strongly modified river sides by tree cutting and waste deposits. The snail diversity in this area is very low, only some ubiquist species being present, as is the case of Helix pomatia, Fruticicola fruticum, Euomphalia strigella and Cepaea vindobonensis. Among them, some species develop large populations, considering the microhabitat conditions. Therefore Fruticicola fruticum and $H$. pomatia are dominant in habitats in which humidity is most likely to be preserved, while in habitats with large variations of humidity a mixed snail community is present including the mentioned species and C. vindobonensi, as well.

One specimen of Drobacia banatica and several fresh empty shells were found in S5 Sadova Veche, despite the strong anthropogenic pressure produced by the fact that the station is located in the vicinity of a waste storage. A cluster analysis was carried out using the relative abundance of land snail species in each one of them (Fig. 2).

Four of the clusters make evident the heterogeneity of the studied area. The most similar are the sampling stations located in the plateau area in highly perturbed habitats (S5, S6 and S7). A second one groups two sampling locations: one from the mountain area (S2) and the second from Teregova Gorges (S4), while the remaining two stations are independent, with a particular land snail community structure in Semenic Mountains (S1), and a disturbed condition by pasture in S3. 


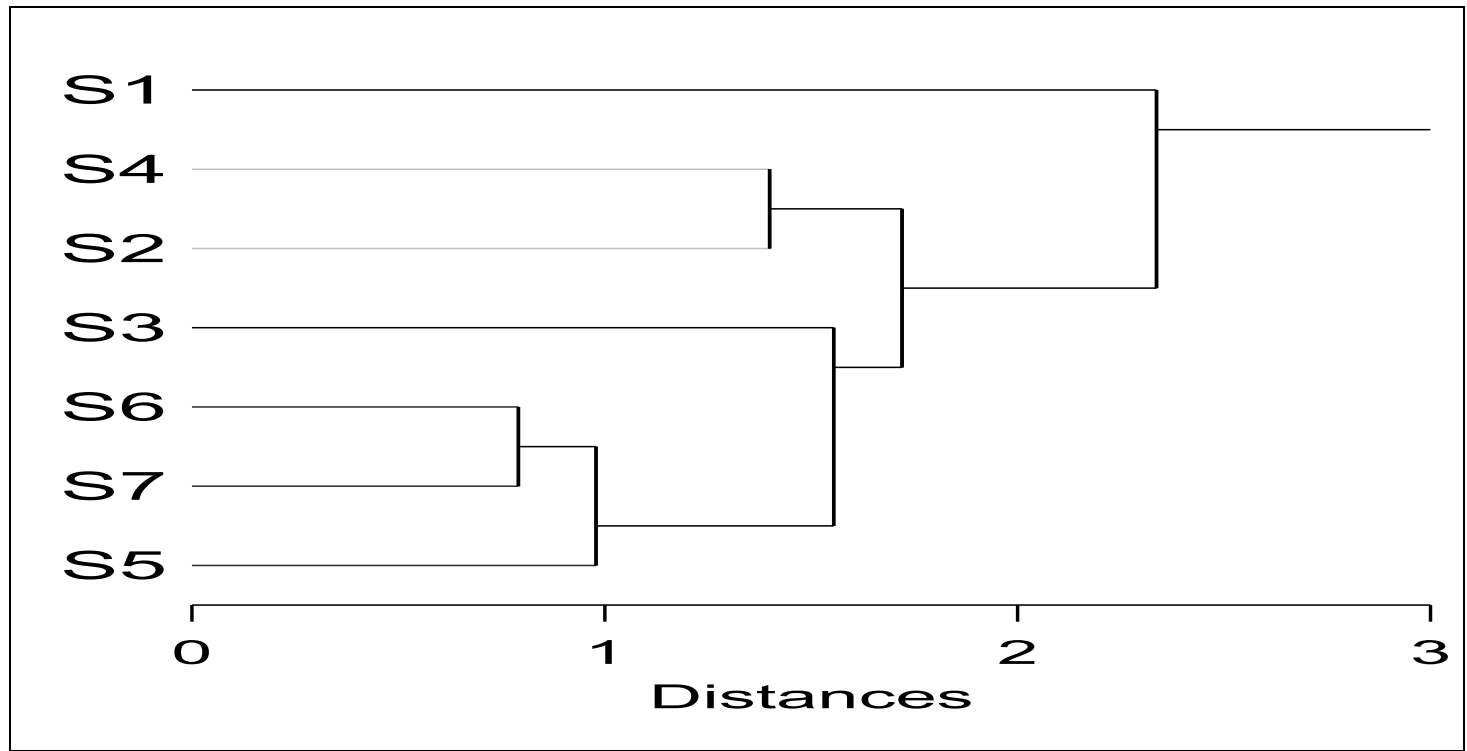

Figure 2: Cluster analysis based on the relative abundance of land snail species in the seven sampling stations (S1- S7).

\section{CONCLUSIONS}

The geology, vegetation and also the extent of the human impact shape the diversity of malacofauna in the area. The reduced diversity underlines the degree of perturbation and the absence of suitable conditions for snail presence. The most common species in the area are ubiquities, like Helix pomatia, Fruticicola fruticum and Euomphalia strigella.

The Banat area is considered the distribution center for Drobacia banatica, a distribution that covers Transylvania, Banat, Crișana, Maramureș (Grossu, 1983; Gheoca et al., 2008; Cameron et al., 2011), eastern Hungary (Fintha et al., 1993; Szabó and Fintha, 1999; Solymlos and Feher, 2005) and western Ukraine (Pelbárt, 1999). The species is generally present in moderated humid forests starting the mountain area up to 1000-1100 m altitudes, but also in lowlands. Regarding this species, we can notice two distinct aspects. First its absence in an area from its distribution center is most likely caused by the increasing human pressure during the recent years. On the other hand we find its presence in the vicinity of a village, near waste deposits, which is quite unexpected. The species presence in such highly anthropized area is probably an evidence of the river's contribution to the land snails dispersion. Such dispersed specimens can survive if they find appropriate conditions, which makes improbable the species long-term survival in the mentioned area.

\section{ACKNOWLEDGEMENTS}

A part of this results came from the scientific study of the quality of the Timiş River water, "Study of the quality of Timiş water and registry of polluters source to border" (IV.1.2), a Phare CBS contract, no. 411 - 90964/30.12.2010/07 of "Lucian Blaga" University, Faculty of Sceinces, financed by the European Community. 


\section{REFERENCES}

1. Bank R. A., 2011 - Fauna Europaea: Mollusca, Gastropoda. Fauna Europaea. Version 2.4, http://faunaeur.org (accessed 18.V.2013)

2. Burton R. F., 1983 - Ionic regulation and water balance, The Mollusca (Saleuddin, A.S.M. and Wilbur K. (eds), 5, Physiology, 2, Academic Press, New York, 291-352.

3. Cameron R. A. D. and Pokrysko B. M. 2005 - Estimating the species richness and composition of land mollusk communities, Journal of Conchologyi, 38, 529-547.

4. Cameron R. A. D., Pokryszko B. M., Horsak M., Sîrbu I. and Gheoca V., 2011 - Forest snail faunas from Transylvania (Romania) and their relationship to the faunas of Central and Northern Europe, Biological Journal of the Linnean Society, 104, 2, 471-479.

5. Fintha I., Sümegi P. and Szilágyi G., 1993 - A new biotope of Chilostoma banaticum (Rossmässler 1838) in Hungary and its nature conservation aspects, Malakológiai Tájékoztató, 12, 29-33.

6. Gheoca V., 2005 - Preliminary note concerning the terrestrial mollusksfauna of the Târnava hydrographic basin, Transylvanian Review of Systematical and Ecological Research, 2, 61-66.

7. Gheoca V., 2007 - Aspects regarding the terestrial malacofauna of the Saxon Villages of Southern Transylvania area, Transylvanian Review of Systematical and Ecological Research, 2, "The Târnava Rivers Basin", 127-134.

8. Gheoca V., Sîrbu M. and Sîrbu I., 2008 - Data concerning the terrestrial gastropod fauna of Muntii Maramureşului Natural Park, Transylvanian Review of Systematical and Ecological Research, 4, 53-58.

9. Grossu A. V., 1981 - Gastropoda Romaniae., Ordo Stylommatophora, 3, Suprafamiliile Clausiliacea şi Achatinacea, Bucureşti, 1-269. (in Romanian)

10. Grossu A. V., 1983 - Gastropoda Romaniae, 4, Ordo Stylommatophora, Suprafamiliile: Arionacea, Zonitacea, Ariophantacea şi Helicacea, Edit. Litera, Bucureşti. (in Romanian)

11. Grossu A. V., 1987 - Gastropoda Romaniae 2, Subclasa Pulmonata, Ord. Basommatophora şi Ord. Stylommatophora: Suprafam. Succineacea, Cochlicopacea, Pupillacea, Edit. Litera, Bucureşti. (in Romanian)

12. Lindenmayer D. B. and Fischer J., 2006 - Habitat Fragmentation and Landscape Change: an Ecological and Conservation Synthesis. Island Press, Washington, DC.

13. Myšák J. and Horsák M., 2011 - Floodplain corridor and slope effects on land mollusc distribution patterns in a riverine valley, Acta Oecologica 37, 2, 146-154.

14. Nekola J. C., 1999 - Paleorefugia and Neorefugia: the influence of colonization history on community pattern and process. Ecology 80, 2459-2473.

15. Pelbárt J, 1999 - Data to the mollusc fauna of the Carpathian Biosphere Reserve, Ukraine (Mollusca), Miscellanea Zoologica Hungarica, 13, 2 T, 85-90.

16. Solymlos P. and Feher Z., 2005 - Conservation Prioritization Based on Distribution of Land Snails in Hungary, Conservation Biology, 19, 1084-1094. Doi: 10.1111/j.15231739.2005.00193.x

17. Szabó A. and Fintha I. 1999 - The third and most significant record of Chilostoma banatica (Rossmässler, 1838) / = Helicigona banatica/ in Hungary (Tiszabecs) flood plain of River Tisza, Tiscia monograph series, 4, 479-480.

18. Ward D. and Slotow R., 1992 - The effects of water availability on the life span of the desert snail, Trochoidea seetzeni, Oecologia, 90, 572-580.

19. Systat Software, 2009 - Systat 12 Getting Started. San Jose, CA. 